\title{
Trends in coronary mortality and community services, associated with occupational structure in New York State, 1980-96
}

\author{
D L Armstrong, D Strogatz, R Wang
}

See end of article for authors' affiliations

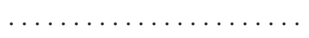

Correspondence to: Dr D Armstrong, University at Albany, SUNY, Department of Epidemiology, SPH, One University Place, Rensselaer NY 12144-3456, USA; dla02@health.state.ny.us

Accepted for publication 11 February 2002

\begin{abstract}
Study objective: Examine the association between county occupational structure, services availability, prevalence of risk factors, and coronary mortality rates by sex, for 1980-96, in New York state.

Design: New York's 62 counties were classified into three occupational structure categories; counties with the lowest percentages of the labour force in managerial, professional, and technical occupations were classified in category I, counties with the highest percentages were in category III. Directly age adjusted coronary heart disease (CHD) mortality rates, aged 35-64 years, (from vital statistics and census data), per capita services (Census County Business Patterns), and the prevalence of CHD risk factors (BRFSS data) were calculated for each occupational structure category.

Results: CHD mortality rates and the prevalence of risk factors were inversely associated with occupational structure for men and women. Income from manufacturing jobs declined most in category I and per capita numbers of producer services for banking, business credit, overall business services, and personnel/employment services were 9-15 times greater in category III compared with I counties. Consumer services such as grocery stores, fitness facilities, doctors offices, and social services were 1.5-4 times greater in category III compared with I counties.

Conclusions: An ecological model for conceptualising communities and health and for intervention design is discussed; key community characteristics are occupational and industrial structure, availability and diversity of consumer services, prevalence of health practices, and level of premature CHD.
\end{abstract}

involving, for example, taxicabs, radio and television broadcasting, gasoline stations, banks, schools, hotels and motels, child care, computer support, repair shops, libraries, legal and accounting services. A definition of service activities is further understood by distinguishing service activities from two other major industry sectors, manufacturing (that is, producing tangible goods) and extraction industries (that is, agriculture, forestry, fishing, mining).

Two broad categories of services that have implications for economic development and geographical distributions of jobs and economic resources, are consumer services and producer services. As implied, consumer services are rendered directly to people, whereas producer services are rendered to firms and represent business or commercial activity (services that appear in both categories may be distinguishable based on the source of the majority of their income). Government services (for example, social services) can represent a substantial contribution to the service sector, especially in countries with nationalised utilities and medical care. Government services are often categorised separately as they can potentially deter overall economic development when competition with privately owned services occurs. Consumer services are more apparently related to public health, for example, the availability and quality of fitness facilities, grocery stores, social services and medical care. However, producer services relate to public health by contributing to the strength of a local economy and the quality and availability of local jobs and wage levels, which indirectly supports the availability of consumer services. ${ }^{11}$

In a previous study in Washington state, an association was observed between county occupational structure, coronary mortality trends and the availability of community services in 1990. ${ }^{5}$ This study expands on previous research by examining the association between occupational structure, coronary mortality trends, and community services in New York state, economic resources and services in communities. ${ }^{911} 12$ The service sector encompasses a wide range of activities described as de-industrialisation and this transformation has influenced both occupational structure in the United States$$
\text { mont }
$$ 
and by examining changes in services availability during 1980 to 1995. In addition, this study analyses additional types of services and discusses the relevance of producer services to public health, as these activities affect the availability and quality of jobs and the strength of a local economy, including the ability of the economy to support health related consumer services.

\section{METHODS}

The proportion of the civilian, employed labour force in selected white collar occupations (that is, managerial, professional speciality, and technical occupations) was used to represent the occupational structure of counties in New York state. Information on the proportion of each county labour force in managerial/professional occupations was obtained from the US Census of Population and Housing in 1980. This information was used to rank the 62 counties by the percentage of the labour force in managerial/professional occupations, and the range between the first and the 99th centiles of the distribution was divided into three occupational structure categories of equal ranges of percentages, which is consistent with previous studies. ${ }^{245}$ Counties with percentages of managerial/professional workers below the first and above the 99th centiles of the distribution were included in categories I and III, respectively. Unlike categorisation by quantiles of numbers of counties, construction of the occupational structure categories based on equal divisions of the range of percentage of managerial/ professional workers allows extrapolation of an observed pattern to the continuous variation in the occupational structure variable. Although the proportion of the labour force in the selected white collar occupations increased overall during the study period, the correlation between 1980 and 1990 distributions is 0.90 , which indicates that the relative position of counties in the distribution was quite stable.

Mortality rates were calculated for New York residents, aged 35-64 years; this age group represents premature mortality ${ }^{13}$ from CHD and permits comparisons of these results with previous analyses. Deaths with underlying causes assigned to ICD-9 codes $^{14} 410-414,402,429.2$ were included as CHD deaths. Population counts were obtained from the US Bureau of Census. Annual CHD deaths and population counts for five year age groups, from 35-64 years, were summed within occupational structure categories. Annual age adjusted CHD mortality rates were calculated by gender and occupational structure category for 1980-96. Rates were calculated by the direct method using the 1970 US population as the standard. To improve the stability of annual mortality rates by occupational structure and gender, a three year moving average was used. For example, the annual rate for 1996, represents an average of observed rates for 1994-96, the rate for 1982, represents an average of observed rates for 1980-82, etc. As data for the calculation of rates represent complete death and population counts during the study period, statistical testing of mortality rates was not used. Furthermore, as all New York counties were included and were categorised rather than randomised into occupational structure categories, there is no basis for observed associations to be attributable to chance resulting from randomisation and statistical testing of differences between categories was not conducted.

Data on populations living in urban areas, per capita income, unemployment, and median house values and education levels were obtained from the US Census of Population and Housing in 1980 and 1990. Population weighted averages of county data were calculated for each category of occupational structure. An "urban" area was defined according to the US census as having at least a population of 50000 , including areas adjacent to a metropolitan area that have greater than 2500 persons and have at least 1000 persons per square mile. ${ }^{15}$ Information on per capita earnings by industry category in 1984 and 1995 were obtained from the City and County Data Book 1988 and 1998, respectively. Information on county business services was obtained from the Census County Business Patterns for 1980, 1985, 1990, 1995. The following Standard Industry Codes ( SICs) were used to represent and sum specific consumer services among counties within occupational structure categories: grocery/food stores (SICs 5400-10), fruits/vegetables markets (SIC 5430); physical fitness facilities (SIC 7991), elementary/high schools (SIC 8210 ), colleges ( SIC 8220), vocational/job training (SICs 8240, 8290, 8330), childcare services ( SIC 8350), general social services (SICs 8300-90), physicians offices/clinics (SIC 8010), dentist offices (SIC 8020), nursing/personal care facilities ( SIC 8050), hospitals (SIC 8060), drug stores (SIC 5910), commercial banks/savings institutes/credit unions (SICs 6020, 6030, 6060 ), civic/social organisations (SIC 8640), labour organisations (SIC 8630), business organisations (SIC 8610). In addition, the following codes were used to represent and sum producer services: transportation and public utilities (SICs 40004999); communication (4800-90); finance, insurance, real estate (SICs 6000-6999); banking (SICs 6000-6280); business credit (SIC 6150); insurance carriers (SICs 6300-6400); real estate (SICs 6500-99); business services (SICs 7300-89); advertising (SICs 7310-19); security (SICs 7381-2); personnel/employment services (SICs 7360-1, 7363); legal (SIC 8100); architectural (SICs 8712-3); accounting (SIC 8720); management/public relations (SICs 8740-3).

Data on the prevalence of selected self reported CHD risk factors were obtained from the New York State Behavioral Risk Factor Surveillance Surveys (BRFSS) for 1991 to 1996. The BRFSS is an ongoing telephone survey of noninstitutionalised New York state adults. Response data were summed across counties within each occupational structure category. These sums were weighted according to a standard methodology developed by the Centers for Disease Control, which adjusts for the number of telephone numbers and adults in each household and the demographic distribution of the sample by age, race, and gender (post-stratification weighting, weights developed by the Centers for Disease Control and Prevention). People were considered to be "physically inactive" if they reported "no leisure time physical activity" or "activity totalling less than 20 minutes per day, three days or less per week." Men and women were considered to be "overweight" if their body mass index was greater than $27.8 \mathrm{~kg} / \mathrm{m}^{2}$ and $27.3 \mathrm{~kg} / \mathrm{m}^{2}$, respectively.

\section{RESULTS}

\section{Characteristics of occupational structure categories}

In 1980, the proportion of the labour force in managerial/ professional occupations in New York counties ranged from $16 \%$ to $44 \%$ (table 1). Occupational structure category I represented counties with the smallest proportions of managerial/ professional workers, 16-24\%, and category III represented counties with the largest proportion of managerial/ professional workers, $34 \%-44 \%$. Category I represented $32 \%$ of the population of New York state and $64 \%$ of residents in these counties lived in urban areas, compared with $95 \%$ of category III residents. Mean education and income levels increased with occupational structure category; with 3.0 times the proportion of the population 25 years and older holding a (bachelors or higher) college degree in category III (31\%) compared with category I counties (11\%). Average annual per capita income was 1.8 times greater in category III compared with category I in 1980; and this ratio increased to 2.2 times in 1990. Per capita income from capital, investment resources (stocks, dividends, rent) was 3.2 times greater in category III compared with category I in 1980; and this ratio increased to 4.3 in 1990.

Table 2 shows the distribution of per capita earnings for goods related manufacturing and subsectors of the service 
Table 1 Demographic and economic characteristics of populations in each occupational structure category in 1980 (selected 1990 values in parentheses)

\begin{tabular}{|c|c|c|c|}
\hline & \multicolumn{3}{|c|}{ Occupational structure category } \\
\hline & I & II & III \\
\hline Percent of labour force in white collar occupations & $16-24$ & $25-33$ & $34-44$ \\
\hline Number of counties & 35 & 23 & 4 \\
\hline New York State population (\%)* & 32 & 53 & 15 \\
\hline \multicolumn{4}{|l|}{ Percent of population in each category: } \\
\hline Living in an urban area $\dagger$ & 64 & 83 & 95 \\
\hline With a college degreef (1990 value) & $11(15)$ & $18(23)$ & 31 (39) \\
\hline Unemployed§ & 9 & 6 & 6 \\
\hline \multicolumn{4}{|l|}{ Per capita annual income in dollars (1990 value) } \\
\hline Total & $5755(11725)$ & 7729 (16702) & $10360(25874)$ \\
\hline Net from interest, dividends, rent** & $304(640)$ & 466 (1127) & $976(2731)$ \\
\hline
\end{tabular}

industry in 1984, by occupational structure category. Per capita earnings were positively associated with occupational structure category for each industry category shown. However, the greatest disparity in per capita earnings between occupational structure category III and I was in the finance, insurance, and real estate subsector category (III/I ratio, 40.3). The disparity in per capita earnings between categories III and I was least for goodsrelated manufacturing (III/I ratio, 3.2).

Table 2 also shows the percentage of total per capita earnings represented in goods related manufacturing and service industry categories in 1984 and 1995. In all occupational structure categories the percentage of total earnings from goods related manufacturing declined substantially between 1984 and 1995, with the greatest decline observed in category I ( $26.1 \%$ to $16.9 \%)$. This was mainly compensated for by increasing percentages of per capita income from the sub- sector category services, with the greatest percentage increase observed in category I ( $23.1 \%$ to $33.4 \%)$. The only other industry category showing a general increase in per capita income was finance, insurance, and real estate, but the increase was largely limited to occupational structure category III (21.6\% to $27.2 \%$ ). Furthermore, in 1984 per capita income from this subsector was 40.3 times greater in occupational structure category III compared with I.

In 1980 there was a positive association between per capita numbers of establishments providing producer services and occupational structure, for all services shown except real estate (table 3). A pattern of dramatically greater numbers of establishments in category III compared with category I counties was apparent in 1980 and 1995 despite growth in the numbers of establishments in category I counties for many types of producer services. Especially striking in 1995, were

Table 2 Per capita earnings in 1984 and 1995 and percentage of total earnings, from manufacturing and service industry categories, by occupational structure category

\begin{tabular}{|c|c|c|c|c|}
\hline \multirow[b]{2}{*}{ Per capita earnings, dollars (\% total)* } & \multicolumn{4}{|c|}{ Occupational structure category } \\
\hline & 1 & II & III & $\begin{array}{l}\text { Ratio III/I } \\
\text { earnings }\end{array}$ \\
\hline \multicolumn{5}{|l|}{ Goods related manufacturing } \\
\hline 1984 & $1194(26.1)$ & $2146(25.8)$ & $3891(12.6)$ & 3.2 \\
\hline 1995 & $1343(16.9)$ & $2444(17.0)$ & $5278(8.6)$ & 3.9 \\
\hline \multicolumn{5}{|l|}{ Service industry } \\
\hline \multicolumn{5}{|l|}{ Retail trade } \\
\hline 1984 & $453(9.9)$ & $772(9.3)$ & $1666(5.4)$ & 3.7 \\
\hline 1995 & $723(9.1)$ & $1342(9.4)$ & $2519(4.1)$ & 3.5 \\
\hline \multicolumn{5}{|l|}{ Finance, insurance, and real estate } \\
\hline 1984 & $165(3.6)$ & $431(5.2)$ & $6656(21.6)$ & 40.3 \\
\hline 1995 & $381(4.8)$ & $985(6.9)$ & $16657(27.2)$ & 43.7 \\
\hline \multicolumn{5}{|l|}{ Services } \\
\hline 1984 & $1057(23.1)$ & $1848(22.2)$ & $8253(26.8)$ & 7.8 \\
\hline 1995 & $2652(33.4)$ & $4352(30.3)$ & 20729 (33.9) & 7.8 \\
\hline \multicolumn{5}{|l|}{ Government } \\
\hline 1984 & $763(16.7)$ & $1307(15.7)$ & 4437 (14.4) & 5.8 \\
\hline 1995 & $1474(18.6)$ & $2421(16.9)$ & $7814(12.8)$ & 5.3 \\
\hline \multicolumn{5}{|l|}{ Other industry categories $\dagger$} \\
\hline 1984 & $943(20.6)$ & $1806(21.8)$ & $5921(19.2)$ & 6.3 \\
\hline 1995 & $1357(17.2)$ & $2800(19.5)$ & $8116(13.4)$ & 6.0 \\
\hline Total earnings 1984 & $4575(100)$ & $8310(100)$ & $30824(100)$ & 6.7 \\
\hline Total earnings 1995 & $7930(100)$ & $14344(100)$ & $61113(100)$ & 7.7 \\
\hline
\end{tabular}

*Data for 1984 from the County and City Data Book 1988, and data for 1995 from the County and City Extra 1998. †Other industry categories: agriculture, forestry, mining, construction; transportation, communications and other public utilities; wholesale trade. 
Table 3 Per capita numbers of producer services establishments in 1980 and percentage change in numbers of establishments 1980 to 1995 , by occupational structure category

\begin{tabular}{|c|c|c|c|c|c|c|c|c|}
\hline \multirow[b]{3}{*}{$\begin{array}{l}\text { Per capita* numbers of establishments } \\
\text { (percentage change } 1980 \text { to 1995) } \neq\end{array}$} & \multicolumn{8}{|c|}{ Occupational structure category } \\
\hline & \multirow{2}{*}{\multicolumn{2}{|c|}{1}} & \multirow{2}{*}{\multicolumn{2}{|c|}{ II }} & \multirow{2}{*}{\multicolumn{2}{|c|}{ III }} & \multicolumn{2}{|c|}{ Ratio III/I } \\
\hline & & & & & & & 1980 & 1995 \\
\hline Transportation and public utilities $\uparrow$ & 135 & (25) & 167 & (41) & 418 & $(-7)$ & 3.1 & 2.3 \\
\hline Communication§ & 14 & (57) & 14 & (143) & 36 & (105) & 2.6 & 3.4 \\
\hline Finance, insurance, real estate & 286 & (16) & 332 & (22) & 1362 & (22) & 4.8 & 5.0 \\
\hline Banking I & 54 & (13) & 83 & (39) & 260 & (115) & 4.8 & 9.2 \\
\hline Business credit & 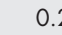 & (94) & 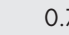 & (149) & & $5(12)$ & 37.5 & 27.1 \\
\hline Insurance carriers & 50 & $(-35)$ & 91 & $(-14)$ & 194 & $(-40)$ & 3.9 & 3.5 \\
\hline Real estateף & 174 & (34) & 146 & (38) & 798 & (8) & 4.6 & 3.7 \\
\hline Business services & 39 & (187) & 126 & (166) & 723 & (51) & 18.5 & 9.8 \\
\hline Advertising & 2 & $(100)$ & 9 & (67) & 79 & (18) & 39.5 & 25.1 \\
\hline Security & 1 & (200) & 3 & (167) & 8 & (50) & 8.0 & 4.0 \\
\hline Personnel/employment & 2 & (254) & 10 & (115) & 64 & (64) & 32.0 & 20.7 \\
\hline Legal & 51 & $(-41)$ & 89 & $(-26)$ & 285 & $(-37)$ & 5.6 & 6.0 \\
\hline Architectural & 4 & (0) & 11 & $(-27)$ & 33 & $(-9)$ & 8.2 & 7.5 \\
\hline Accounting & 6 & $(100)$ & 17 & (88) & 54 & (19) & 9.0 & 5.3 \\
\hline Management/public relations & 2 & (850) & 10 & (440) & 87 & (192) & 43.5 & 13.4 \\
\hline \multicolumn{9}{|c|}{ 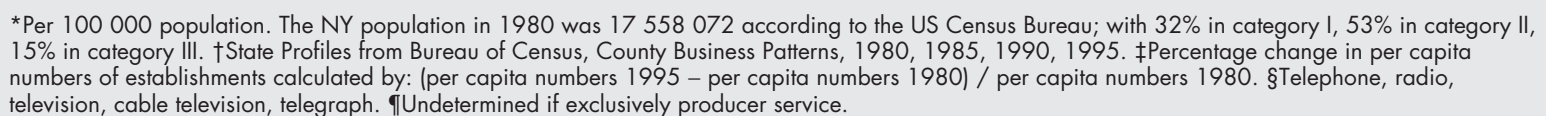 } \\
\hline
\end{tabular}

the numbers of establishments in category III compared with category I describing banking (9.2 times), business credit (27.1), business overall (9.8), personnel and employment (20.7), and management (13.4) services. Numbers of establishments providing insurance, including medical insurance, declined in all areas, as did legal services.

Per capita numbers of establishments for consumer services, by occupational structure category, are shown in table 4. In 1980, counties in category III had the greatest per capita numbers of establishments for every service. There were 6.8 times the number of job training services, 2.7 times the number of fitness facilities, 1.6 times the number of childcare services, 1.5 times the number of grocery and fruit/vegetable markets in category III compared with category I counties. Between 1980 and 1995, there was little change in the ratio of per capita numbers of establishments between category III and I for many services shown; however, there was some decrease in the ratio describing educational services. The ratio of per capita numbers of establishments between category III and I also increased for fitness facilities (from 2.7 to 4.2 ), because of a decline in numbers of fitness facilities in category I counties. More modest increases in the gap between categories III and I were observed for medical and dental care establishments. In both 1980 and 1995, there were at least two

Table 4 Per capita numbers of consumer services establishments in 1980 and percentage change in numbers of establishments 1980 to 1995 , by occupational structure category

\begin{tabular}{|c|c|c|c|c|c|}
\hline \multirow[b]{3}{*}{$\begin{array}{l}\text { Per capita* numbers of establishments† (percentage change } 1980 \text { to } \\
\text { 1995) } \neq\end{array}$} & \multicolumn{5}{|c|}{ Occupational structure category } \\
\hline & \multirow[b]{2}{*}{1} & \multirow[b]{2}{*}{ II } & \multirow[b]{2}{*}{ III } & \multicolumn{2}{|c|}{ Ratio III/I } \\
\hline & & & & 1980 & 1995 \\
\hline Grocery/food stores & 111 (27) & $112(25)$ & $167(27)$ & 1.5 & 1.5 \\
\hline Fruit/vegetable markets & $2(57)$ & $2(-7)$ & $4(56)$ & 1.6 & 1.6 \\
\hline Physical fitness facilities§ & $2(-3)$ & $3(29)$ & $5(32)$ & 2.7 & 4.2 \\
\hline Elementary/high schools & $6(42)$ & $6(22)$ & $12(5)$ & 2.0 & 1.5 \\
\hline Colleges & $0.8(48)$ & $1(13)$ & $4(-6)$ & 5.4 & 3.4 \\
\hline Vocational/job training services & $2(220)$ & $4(183)$ & $14(100)$ & 6.8 & 4.2 \\
\hline Child care services§ & $10(29)$ & $12(32)$ & $16(13)$ & 1.6 & 1.4 \\
\hline General social services & $23(144)$ & $23(166)$ & $50(128)$ & 2.1 & 2.0 \\
\hline Doctor offices/clinics & $47(7)$ & $68(29)$ & $148(15)$ & 3.1 & 3.4 \\
\hline Dentist offices & $28(-3)$ & 45 (12) & $64(16)$ & 2.2 & 2.7 \\
\hline Hospitals & $2(-8)$ & $2(3)$ & $3(-9)$ & 1.4 & 1.3 \\
\hline Commercial banks, savings institutes, credit unions & $16(36)$ & $24(40)$ & $42(9)$ & 2.6 & 2.1 \\
\hline Civic and social organisations $\uparrow$ & 10 (17) & $8(29)$ & 17 (37) & 1.7 & 2.0 \\
\hline Labour organisations $\uparrow$ & $5(-1)$ & $8(-3)$ & $19(-30)$ & 3.8 & 2.7 \\
\hline Business organisations $\mathbb{f}$ & $2(4)$ & $3(23)$ & $18(-31)$ & 9.9 & 6.5 \\
\hline Total square miles** & 30039 & 16075 & 1111 & & \\
\hline \multicolumn{6}{|c|}{ 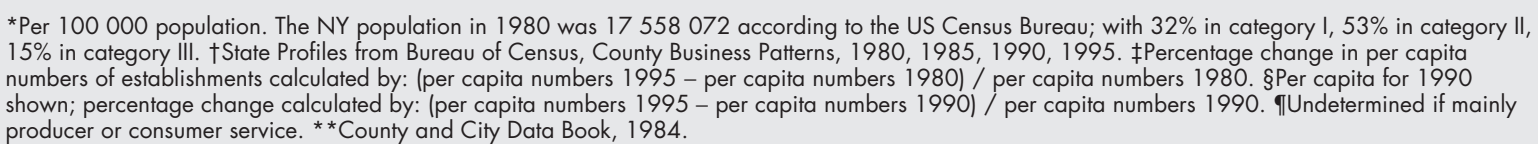 } \\
\hline
\end{tabular}




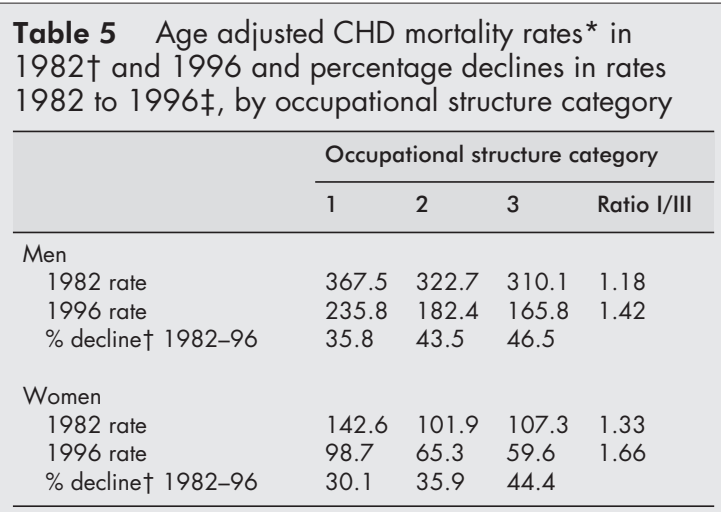

*Age adjusted rates, for ages 35 to 64 years, by the direct method of adjustment, using the 1970 US population as the standard. TRates computed using a three year moving average; rate shown for 1982 is an average of rates for 1980-1982, rate shown for 1996 is an average of 1994-1996. $\ddagger($ rate 1980 - rate 1996) / rate 1980. times the per capita numbers of civic and social organisations, and labour and business organisations in category III compared with category I counties.

\section{CHD mortality}

Table 5 shows age adjusted CHD mortality rates by occupational structure category in 1982 and 1996, separately for women and men. For both women and men, an inverse association between CHD mortality and occupational structure was observed, with the lowest rates observed in counties with the highest proportions of the labour force in managerial/professional occupations. Among women, the mortality rate ratio for category I compared with category III was 1.33 in 1982 and 1.66 in 1996. Among women, differences in mortality between category II and I appear small (data not shown). Among men, the mortality rate ratio for category I compared with category III was 1.18 in 1982 and 1.42 in 1996. Among women and men, the rate of coronary mortality decline during 1982-96 was positively associated with occupational structure category; such that among men, mortality in category III counties decreased $46.5 \%$ compared with $35.8 \%$ in category I counties. Women showed an even greater disparity in percentage decline by occupational structure category, with $44.4 \%$ in category III compared with $30.1 \%$ in category 1 .

\section{Prevalence of health risk factors}

Table 6 shows the percentage prevalence of selected self reported health risk factors by gender and occupational structure category. Among both men and women, the highest prevalence of current smoking, overweight, and physical inactivity was among residents of occupational structure category I counties. The prevalence of overweight in occupational structure category I compared with III was 7.6 percentage points higher among men and 11.2 percentage points higher among women. A positive association in the prevalence of persons eating at least three servings daily of fruits and vegetables was observed among both men and women. There was an inverse association between poor mental health days and occupational structure category among women but not for men; men residing in category III counties reported the greatest number of such days per month during 1991.

\section{DISCUSSION}

Results from this study show that CHD mortality rates were inversely associated with level of occupational structure in New York counties, and percentage declines in rates during 1982 to 1996 were directly associated with occupational structure. In all occupational structure categories the percentage of total earnings from the industry subsector "goods related manufacturing" declined substantially between 1984 and 1995, with the greatest decline observed in category I counties $(26.1 \%$ to $16.9 \%$ ) (table 2 ). There were substantially greater numbers of establishments providing producer or business related services in occupational category III compared with category I counties, especially services providing banking (ratio III/I, 9.2) and business credit (ratio 27.1), overall business services (ratio 9.8) and personnel/employment services (ratio 14.9) (table 3). For consumer services, ratios comparing per capita numbers of establishments in category III with category I counties were less dramatic than observed for producer services but still substantial, such as grocery stores (ratio III/I, 1.5), fitness facilities (ratio 4.2), doctors

Table 6 Estimated prevalence of coronary risk factors in 1991, by gender and occupational structure category

\begin{tabular}{|c|c|c|c|}
\hline \multirow[b]{2}{*}{ Estimated* prevalence \%†, 1991} & \multicolumn{3}{|c|}{ Occupational structure category } \\
\hline & 1 & II & III \\
\hline \multicolumn{4}{|l|}{ Men } \\
\hline Current, regular smokers & 26.0 & 22.7 & 24.0 \\
\hline Physically inactive $\neq$ & 63.9 & 58.2 & 57.4 \\
\hline Overweight§ & 30.4 & 27.0 & 22.8 \\
\hline Eat at least 3 servings/day of fruits and vegetables & 64.7 & 65.5 & 78.8 \\
\hline \multicolumn{4}{|l|}{ Average number of days in the past month reported: } \\
\hline poor mental health & 9.4 & 8.3 & 10.2 \\
\hline poor physical health & 7.2 & 7.2 & 7.5 \\
\hline \multicolumn{4}{|l|}{ Women } \\
\hline Current, regular smokers & 22.4 & 21.0 & 17.5 \\
\hline Physically inactivef & 65.3 & 62.8 & 52.0 \\
\hline Overweight§ & 29.6 & 22.2 & 18.4 \\
\hline Eat at least 3 servings/day of fruits and vegetables & 68.7 & 70.2 & 75.8 \\
\hline \multicolumn{4}{|l|}{ Average number of days in the past month reported: } \\
\hline poor mental health & 9.4 & 8.8 & 8.3 \\
\hline poor physical health & 7.9 & 9.1 & 7.8 \\
\hline
\end{tabular}


offices (ratio 3.4) and social services (ratio 2.0) (table 4). Consistent with patterns of mortality and the availability of services related to health, the prevalence of selected coronary risk factors including the percentage of the population who were overweight, physically inactive, and current smokers was inversely associated with county occupational structure for men and women (table 6).

These results are consistent with a previous study in Washington state ${ }^{5}$ that observed an association between county occupational structure, premature coronary mortality, the availability of local (mainly consumer) services, and the prevalence of risk factors related to CHD. In addition, this previous study observed an association between county occupational structure, median home values, and county tax base and expenditures, which may be expected as property taxes represent much of the funding source for county infrastructure and local communities. Thus the percentage of a community labour force in "upper" white collar jobs represents local wage, education, and skill levels of the local population, and communities with higher occupational structure are able to support higher property values and provide for greater local expenditures and infrastructure.

Compared with the manufacturing sector, the service sector has a higher share of high skill and low skill jobs but a relatively smaller share of medium skill jobs. ${ }^{11}{ }^{16}$ Producer services account for most of the percentage growth in service employment, and these jobs overall require higher education levels and emphasise skills in creativity, flexibility, independence, and responsibility. There is an increasing demand for producer services as markets have become more international and unpredictable and marketing, advertising, and distribution functions have become much more demanding. Such producer services now may constitute as much as $90 \%$ of overall manufacturing costs and include product development; marketing and administration; production planning; transport and storage; other services provided within a company or obtained externally (for example, legal, accounting, specialised advertising/marketing). ${ }^{11}$ Product innovation to meet diversified and changing market demands is emphasised in today's economy, with adaptation of products to specialised demand rather than prices being the crucial parameter of competition. ${ }^{11}{ }^{17}$ However, especially in the United States the service sector also includes in absolute terms a large number of low skill, low wage service jobs (for example, sales and bank clerks, truck drivers). ${ }^{7911}$

Therefore, occupational structure changes have accompanied industrial restructuring and transformation to a services economy in the United States. ${ }^{7818}$ A substantial decrease in the number of goods manufacturing jobs in the United States occurred in recent decades, representing largely machine operatives occupations that tended to be medium skilled, higher paying, union jobs. ${ }^{819}$ However, these displaced blue collar workers typically lacked the formal education and training to qualify for better services jobs and instead tended to transition to lower wage services jobs. ${ }^{10}{ }^{1120-22}$ Furthermore, low skill, low wage service jobs are disproportionately held by women, the black population, and Hispanics. ${ }^{20}{ }^{23-25}$

Therefore, transformation to a services economy, along with stagnating wages for the majority of workers may be fundamental mechanisms resulting in increasing income inequality in the United States. ${ }^{19226}$ One study of income trends by education observed decreasing (real) wages during 1979-89 for all educational levels except college graduates, ${ }^{22}$ which represented only $20 \%$ of US residents in 1990 ( 25 years and older) and $7 \%$ with graduate or professional degrees (STFl, Census dataset). Furthermore, income inequality between higher skilled and lower skilled occupations translates into community disparities in economic resources because of differences in county occupational structure.

Producer services are highly connected with the structure of national and local economies and the importance of these activities to a local industrial structure, in addition to manufacturing, has only recently been recognised..$^{7118}$ Producer services provide strategic services to agricultural, manufacturing, or other services, which would be less competitive if they did not have access to these services in their proximity. This is especially true for smaller client organisations (unlike corporate headquarters that obtain such services internally) and these comparatively less sophisticated businesses are numerous and especially important in community economies located outside of major metropolitan areas. Therefore, the presence of producer services represents a business climate conducive to economic growth and overall competitiveness. ${ }^{1127}$ In addition, the strength of a local economy assures adequate demand for consumer services (more immediately related to health) and the presence of consumer services contributes to the attractiveness of localities and influences the residential preferences of skilled workers. ${ }^{112028}$

Several factors influence the geographical location of producer services inter-nationally and intra-nationally including proximity to clients, transportation and communication infrastructure (for example, airport, telecommunications services), access to information (for example, libraries, government documentation, computerised data), and labour force skills and education. ${ }^{11}$ Economies of developed countries tend to specialise in producer services such as trading, transport (for example, shipping) and investment services, especially activities such as banking and finance, insurance, scientific and professional services (such as, engineering, accounting, legal). ${ }^{9}$ Whereas, economies of less developed countries emphasise travel and other consumer type services.' Furthermore, both the level of existing producer services and the potential for developing additional producer services in a national or local economy reflects and depends on the labour force professional skills and technical capacity.

The degree of specialisation of a producer service influences the geographical size of its market and reflects a balance between demand for the service and cost of acquiring the service, including the cost of travel and personal time spent accessing the service. This balance also is relevant to consumer services and as these services tend to be general rather than specialised (for example, grocery store, fitness facility) their sustainability is very sensitive to costs of travel and access relative to the demand for the service. ${ }^{11}$ Therefore, if motivations for health practices are relatively low in certain population subgroups, ${ }^{29-31}$ then health related services need to be more readily accessible and entail lower costs in time and travel to encourage their use and thus continued availability. This may, in part, explain the decline in per capita numbers of fitness facilities in occupational structure category I compared with increasing numbers of these establishments in categories II and III (table 4). Before the 1960s, services were located with consideration of consumer travel and time costs, which also reflected a social commitment in the United States to geographical distribution of services and equity. ${ }^{11}$ However, in recent decades considerations of economies of scale and profit have assumed precedence over accessibility and equity, ${ }^{11}$ which, for example, resulted in numerous hospital closings in rural areas $^{32-34}$ and concentrations of medical care providers and specialists, especially in metropolitan areas. ${ }^{4}$ Therefore, increasing emphasis on profitability, sacrificing geographical equity of services, may have affected many additional services other than medical care that are directly and indirectly related to health such as grocery stores, fitness centres, childcare and education services, etc.

There are limitations of the data used in this study including a lack of information on the size of businesses and the quality of services provided. Higher costs and fewer selections of food have been documented in poorer compared with more affluent neighbourhoods. ${ }^{35-39}$ These data do not provide information on differences in the quality of services between occupational structure categories that may occur for a wide range 


\section{Key points}

- CHD mortality rates and the prevalence of risk factors were inversely associated with community occupational structure (\% white collar jobs)

- Income from manufacturing declined most in category I (fewest \% white collar workers).

- Per capita numbers of services for banking, business credit, overall business services, and personnel/employment services were 9-15 times greater in category III (highest \% white collar jobs) compared with category I.

- Consumer services such as grocery stores, fitness facilities, doctors' offices, and social services were 1.5-4 times greater in catergory III compared with I.

- An ecological model for conceptualising communities and health is discussed; key community characteristics are occupational and industrial structure, availablitity and diversity of services.

of services including child care, physical fitness facilities, grocery stores, and medical care. Also, data were unavailable to document distributions of "backroom" producer services, which are routine, lower skilled, and lower paying producer services (for example, data entry in banking, insurance businesses), ${ }^{8}{ }^{10}$ and these types of jobs are commonly located in rural and economically disadvantaged communities. ${ }^{911} 40$ Information on the validity of self reported CHD risk factor data by occupational structure category were unavailable. However, in a previous study the sensitivity of self reported information on smoking and obesity were $74 \%$ and $82 \%$, respectively; specificity was reported to be at least $85 \%{ }^{41}$ Also, as the risk factor prevalence variables were collected beginning in 1991, the analysis of trends from 1980, similar to economic and services data, was not possible. As the purpose of this study was to characterise communities and not individuals and as the county was used consistently as the unit of analysis, this study was not subject to limitations of "ecological fallacy." ${ }^{42-44}$

New York coronary mortality trends during 1982 to 1996 show increasing disparities in mortality between counties characterised by occupational structure (table 5). This suggests unequal distribution of those beneficial community conditions contributing to overall CHD mortality declines. Despite some improvement, substantial and persistent disparities were shown between occupational structure categories for many of the community economic and services indicators during 1980 to 1996. In the context of large disparities, correspondence between trends in community services availability and mortality trends may appear subtle and key community conditions, potentially contributing to CHD declines, difficult to identify. In addition, a lack of sufficient detail, showing specific services occupations within the services category (table 2), may obscure differential distributions of higher skilled compared with lower skilled service jobs across occupational structure categories, and changes in this distribution over time. However, influential effects are suggested by the magnitude of disparities between occupational structure categories for some characteristics such as the prevalence of college educated and the unemployment percentage (table 1); per capita income from finance, insurance and real estate services (table 2); overall availability of producer services, particularly disparities in banking and business credit services (table 3); per capita availability of education, job training and employment services and increasing disparities in medical services (table 4). Furthermore, a change in the level of disparities may not be necessary in order to result in increasing inequalities in CHD mortality, if some community conditions assume greater importance over time because of changes in regional, national, and international economies. ${ }^{45}$ Therefore, changes in the context in which effects of community conditions on health are evaluated could result in variations in the magnitude of associations at different points in time.

This ecological health model has implications for epidemiology methods examining community environments as explanations of risk factor and disease distribution $\mathrm{s}^{46-50}$ and current heart disease prevention strategies that aim to address community environments. ${ }^{51-55}$ Thus, the ecological model conceptualises risk factors and CHD rates, occupational and industrial structure, consumer and producer services, and other aspects of community infrastructure to be highly interdependent. Therefore, it is not meaningful to quantify statistically "independent" contributions to health outcomes of population characteristics (for example, per capita income, percentage with college degree), risk factor prevalence (for example, percentage overweight) and community services (for example, per capita grocery stores) and community conditions (for example, housing stock quality). Rather we wish to describe how commonly these conditions coexist in communities and to better understand the relations between all of these community level characteristics and health outcomes including CHD mortality levels. By the same reasoning, health promotion programmes that seek to improve the prevalence of risk factors and selected health related consumer services but disregard characteristics of the local labour market (for example, education and wage levels; under-employment and unemployment) and other aspects of community economies (such as, industrial structure) are expected to show limited success according to this ecological model.

The strength and sustainability of a local economy reflects a complex set of conditions including the historical and current relative position of a community in larger social, political, and economic environments. ${ }^{11} 1245$ Community assessments need to consider general characteristics of a local economy but should also identify specific characteristics and resources (such as, natural resources, producer and/or consumer services), which may afford a unique sustainable advantage to a given community. Results showing an association between occupational structure and CHD mortality suggest potential direct public health benefits of various development strategies including improved education and job training opportunities in economically disadvantaged communities. The United States has an especially large percentage of service workers employed in low wage, low skill jobs compared with other developed countries. ${ }^{7911}$ Therefore, strategies could include improved educational, especially college, opportunities for lower income populations; decreasing overall wage differentials between "upper" white collar and other workers; tackling inadequacies of the "minimum wage" by establishing a "liveable wage," or establishing a "basic income."156-58 Also, economic development programmes could target disadvantaged communities to increase access to capital resources and cultivate local producer and consumer services that are accessible and tailored to strengthen other sectors of a given local economy. These types of approaches, along with more conventional cardiovascular health education and promotion programmes, may be expected to demonstrate greater efficacy as they confront multiple important and interrelated aspects of the community ecology.

\section{Authors' affiliations}

D L Armstrong, D Strogatz, R Wang, Department of Epidemiology, SPH, University at Albany, SUNY, New York, USA

Funding: this work was supported by a grant from the American Heart Association, New York State Affiliate, Inc.

Conflicts of interest: none.

\section{REFERENCES}

1 Sclar ED. Community economic structure and individual well-being, a look behind the statistics. Int J Health Serv 1980;10:563-79. 
2 Wing S, Casper ML, Hayes CG, et al. Changing association between community occupational structure and ischaemic heart disease mortality in the United States. Lancet 1987; ii:1067-70

3 Casper ML, Wing S, Strogatz DS . Variation in the magnitude of black-white differences in stroke mortality by community occupational structure. J Epidemiol Community Health 1991;45:3-7.

4 Armstrong DL, Barnett E, Casper ML, et al. Community occupational structure, medical and economic resources, and coronary mortality among U.S. blacks and whites, 1980-88. Ann Epidemiol

1998:8:184-91.

5 Armstrong DL, Castorina JC. Community occupational structure, basic services, and coronary mortality in Washington state, 1980-94. Ann Epidemiol 1998;8:370-7

6 Falk WW, Lyson TA. High tech, low tech, no tech. Albany, NY: New York State University Press, 1988.

7 Noyelle T. Skills, wages, and productivity in the service sector. San Francisco, CA: Westview Press, 1990.

8 Candilis WO. United States Service Industries Handbook. New York: Praeger, 1988

9 Daniels P. Service Industries: growth and location. New York: Cambridge University Press, 1982.

10 Lewis R. The new service society. London: Longman Group Limited, 1973.

11 Illeris S. The service economy. A geographical approach. New York: Wiley, 1996.

12 Cooper $\mathbf{R}$. The new economic regionalism: a rural policy framework. Annuals of American Academy Political and Social Science 1993;529:34-47.

13 Desenclos JCA, Hahn RA. Years of potential life list before age 65, by race, Hispanic origin, and sex-United States, 1986-1988. MMWR Morb Mortal Wkly Rep 1992;41:13-23.

14 World Health Organisation. Manual of the international statistical classification of diseases, injuries and causes of death. Based on the recommendations of the Ninth Revision Conference, 1975. Geneva: WHO, 1977.

15 Census of Population and Housing, 1990. Summary Tape File 4 Technical Documentation/prepared by the Bureau of the Census. Washington: The Bureau, 1993

16 Wilkonson F. Dynamics of labour market segmentation. New York: Academic Press, 1981.

17 Markusen, A. Profit cycles, oligopoly, and regional development. Cambridge, MA: MIT Press, 1987.

18 Marshall J. Services and uneven development. New York: Oxford University Press, 1988.

19 Wolff EN. Top heavy. New York: Twentieth Century Fund Report, 1995

20 Bluestone B, Harrison B. The deindustrialization of America: plant closings, community abandonment, and the dismantling of basic industry. New York: Basic Books, 1982

21 Massey D. The age of extremes: concentrated affluence and poverty in the twenty-first century. Demography 1996;33:395-412.

22 Bluestone B. The inequality express. Am Prospect 1994;20:81-93.

23 England P, Browne I. Trends in women's economic status. Sociological Perspectives 1992;35:17-51.

24 Browne LE. Taking in each other's laundry-the Service Economy. New England Economic Review 1986; July/August:20-31.

25 Sheets RG,; Nord S, Phelps JJ. The impact of service industries on underemployment in metropolitan economies. Massachusetts: Lexington Books, 1987

26 Braun D. The rich get richer, the rise of income inequality in the U.S. and the world. Chicago, IL: Nelson-Hall, 1991.

27 O'Hara S. Economic development from the ground up: results of a Household Survey of the Hamilton Hill and Vale Neighborhoods in Schenectady, New York. Troy, NY: Department of Economics, Rensselaer Polytechnic Institute, 1997.

28 Cobb JC. Industrialization and southern society 1877-1984. Lexington, KY: University Press of Kentucky, 1984.

29 Marcus BH, Selby VC, Niaura RS, et al. Self-efficacy and the stages of exercise behavior change. Res Q Exerc Sport 1992;63:60-6.

30 Prochaska JO, Belicer WF, Rossi JS, et al. Stages of change and decisional balance for twelve problem behaviors. Diabetes Spectrum 1993;6:38-40.
31 Prochaska JO. Strong and weak principles for progressing from precontemplation to action based on twelve problem behaviors. Diabetes Spectrum 1993;6:41-2

32 US Congress, OTA. Health care in rural America. Washington DC: US Government Printing Office (OTA-H-434-summary), 1990.

33 Mullner R, Rydman R, Whiteis D, et al. Rural community hospitals and factors correlated with their risk of closing. Public Health Rep 1989; 104:315-25

34 Doelker R, Bedics B. Impact of rural hospital closings on the community. Social Work 1989:Nov:541-3.

35 City of New York, Dept of Consumer Affairs. The poor pay more for less. Part I: Grocery shopping. April 1991.

36 Consumers Union of US, Inc. The thin red line, How the poor still pay more. San Francisco, CA: West Coast Regional Office, 1993.

37 Sooman A Macintyre S, Anderson A. Scotland's health-A more difficult challenge for some? The price and availability of healthy foods in socially contrasting localities in the West of Scotland. Health Bull 1993;51:276-84.

38 Mooney C. Cost and availability of healthy food choices in a London health district. J Hum Nutr Diet 1990;3:1 11 1-20.

39 Ellaway A, Macintyre S. Shopping for food in socially contrasting localities. British Food J 2000; 102:52-9.

40 Eaton L. A fine place to live, and leave. A shrinking population shapes Buffalo's psyche. New York Times 2000;Apr 9:33, 38

41 Bowlin SJ, Morrill BD, Nafziger AN, et al. Validity of cardiovascular disease risk factors assessed by telephone interview: the Behavioral Risk Factor Survey. J Clin Epidemiol 1993;46:561-71.

42 Susser M. The logic of ecological: I. The logic of analysis. Am J Public Health 1994:84:825-35.

43 Schwartz S. The fallacy of the ecological fallacy: the potential misuse of a concept and the consequences. Am J Public Health 1994;84:819-24.

44 Schwartz S, Carpenter KM. The right answer for the wrong question: consequences of type III error for public health research. Am J Public Health 1999;89:1 175-9.

45 Taylor PJ. Political geography and the world-economy. In: Burnett AD, Taylor PJ. Political studies from spatial perspectives. New York: Wiley, 1981.

46 Van Korff M, Koepsell T, Curry SG, et al. Multi-level analysis in epidemiologic research on health behaviors and outcomes. Am Epidemiol 1992:135:1077-82.

47 Diez-Roux AV. Bringing context back into epidemiology: variables and fallacies in multilevel analysis. Am J Public Health 1998;88:216-22.

48 Malmstrom M, Sudquist J, Johansson S. Neighborhood environment and self-reported health status: a multilevel analysis. Am J Public Health 1999:89:1181-6.

49 Diez-Roux AV, Nieto J, Muntaner C, et al. Neighborhood environments and coroary heart disease: a multilevel analysis. Am J Epidemiol 1997; 146:48-63

50 Duncan C, Jones K, Moon G. Do places matter? A multi-level analysis of regional variations in health-related behaviour in Britain. Soc Sci Med 1993; $37: 725-33$

51 Brownson RC, Smith CA, Pratt M, et al. Preventing cardiovascular disease through community-based risk reduction: the Bootheel Heart Health Project. Am J Public Health 1996;86:206-13.

52 Fortmann $\mathrm{S}$, Flora J, Winkleby $M$, et al. Community intervention trials: reflections on the Stanford Five-City Project experience. Am J Epidemiol $1995 ; 142: 576-86$

53 Fawcett SB; Sterling TD; Paine-Andrews A, et al. Evaluating community efforts to prevent cardiovascular diseases. Atlanta, GA Centers for Disease Control and Prevention, National Center for Chronic Disease Prevention and Health Promotion, 1995.

54 Oberman A, Kuller LH, Carleton RA. Prevention of cardiovascular disease-opportunities for progress. Prev Med 1994;23:727-32.

55 Haignere CS. Closing the ecological gap: the public/private dilemma. Health Educ Res 1999:14:507-18.

56 Collard D, Lecomber R, Slater M. Income distribution: the limits of redistribution. New York, NY: Wiley, 1979

57 Fitzpatrick T. Freedom and security. An introduction to the basic income debate. London: Macmillan, 1999.

58 Van Parijs P. Real freedom for all. What (if anything) can justify capitalism. Oxford: Oxford University Press, 1995. 